\title{
The effect of awareness raising about using cognitive strategies in foreign language teaching on students' development of reading comprehension skills
}

\author{
Gülper Güvenç ${ }^{1 \mathrm{a}}$ \\ ${ }^{1}$ TOBB University of Economics and Technology, Ankara, 06560, Turkey
}

\begin{abstract}
The purpose of this study is to analyze the development of students' reading comprehension skills about using cognitive strategies in foreign language teaching by means of awareness raising activities. To this end, the research was conducted for 11 weeks with 77 students studying in an English preparatory school program. The experimental group was exposed to a training which is based on awareness raising activities about using cognitive strategies. A pre-test and a post-test were designed for 2 experimental and 2 control groups with random sampling, and then the statistical differences were tested based on the scores of the both groups in terms of significance. Moreover, the study aims to determine the views of the participants about the strategy training. The results show that there was a significant difference between the pre-test and post-test scores of the experimental group in terms of their achievement in reading skill, and the post-test scores of the both experimental group and control group were in favor of the experimental group. Also, it has also found that the experiment had a positive impact on the participants.

Keywords: reading comprehension; reading strategies, cognitive strategies, language learning strategies
\end{abstract}

\section{Introduction}

Language teaching is based on four skills which are reading, writing, listening and speaking, and structure. Among these four skills, reading is one of the most significant communication and perception skills. Demirel [5] defines reading as the inference from written symbols through the collaborative activity of cognitive behavior with psychomotor skills. In particular, one focus of research in the area of EFL is concerned with applying language learning strategies which is considered to have an influence on the process of improving reading skill. In this context, it is fundamental to know and apply various strategies, techniques and methods to enable students to improve their progress in

\footnotetext{
${ }^{\text {a } C o r r e s p o n d i n g ~ a u t h o r: ~ g u l p e r g u v e n c @ h o t m a i l . c o m ~}$
} 
acquiring, storing, retaining, and using information in reading skill. Thus, the current study has been conducted within the scope of language strategy research in reading contexts.

According to Oxford [11], one of the first to carry out research in this area, "learning strategies are specific actions taken by the learner to make learning easier, faster, more enjoyable, more self-directed, more effective, and more transferrable to new situations". What turns a reading activity into a learning strategy is practicing it consciously. Although there are a number of studies about improving reading comprehension skill $[1,6,7,8,9$, 13, 16, 17 and 19] the potential strategies to be used in reading lessons are generally neglected or are not applied in a proper way. The term language strategy has been emphasized by various researchers. Rubin [15] state that learning strategies are "... any sets of operations, steps, plans, routines used by the learner to facilitate the obtaining, storage, retrieval, and use of information." Richards and Platt [14] define learning strategies as "intentional behavior and thoughts used by learners during learning to better help them understand, learn, or remember new information."

While language learning strategies were categorized in several ways by various researchers [10,15], Oxford [11] took this process a step further. In her Strategies Inventory for Language Learning (SILL) she highlighted six categories namely: Memory strategies (e.g., grouping, representing sounds in memory), cognitive strategies (e.g., repeating, analyzing, getting the idea quickly and taking notes), compensation strategies (e.g., switching to the mother tongue, using other clues), metacognitive strategies (e.g., linking new information with already known one, self-monitoring), affective strategies (lowering anxiety by use of music, encouraging oneself and discussing feelings with others) and social strategies (asking for clarification, cooperating with others and developing cultural understanding). The present study has been conducted based on Oxford's taxonomy since it is comprehensive, detailed and systematic [18]. Besides, it links with each of the four language skills of listening, reading, speaking and writing, and it is reliability and validity is remarkable across many cultural groups [12].

It is anticipated that the higher the students' awareness about strategy usage, the better they choose strategies that fit their learning style. Therefore, these strategies become a useful instrument for active, conscious and purposeful self-regulation of learning. As all universities have a different level and program of English preparatory class education, it is especially compelling for the students who are supposed to take a test like TOEFL, which necessitates a higher level of knowledge in English, and who have difficulty in concentrating on quite long reading passages at the end of preparatory school. Therefore, cognitive strategies are like a tactic for students especially in reading passages having multiple choice questions. It is remarkable that there are many studies about foreign language education, reading comprehension skill, teaching methods together with learning strategies, yet very few researches are held about reading comprehension and strategy usage, especially the cognitive strategy group. As Oxford [11] states "Cognitive strategies are typically found to be the most popular strategies with language learners". They are based on mental processes about acquiring and processing data.

Based on the research discussed above, language learning strategies, especially cognitive strategies, appear to be a significant issue related to ELT learners' reading skill. Hence, the purpose of this study is to analyze the development of students' reading comprehension skills about using cognitive strategies in the area of EFL by means of awareness raising activities. In this sense, this study can be beneficial for contributing to the foreign language teaching methods as well as for the English instructors. For this purpose, the following questions were addressed in the current research:

1. Is there a significant difference between the comparison of pretest and posttest scores of both experimental and control groups? 
2. Is there a significant difference between posttest scores of both experimental and control groups?

3. What is the overall opinion of the experimental group about the cognitive strategy training program?

\section{Method}

In this study, both qualitative and quantitative methods, in other words mixed methods, were used. The randomized pre-test and post-test control group model was designed for the experimental research. The pre-test and post-test were used for 2 experimental and 2 control groups, and then after the training, the statistical differences were tested based on the test scores of the both groups. Before the main study, a pre-study was conducted in order to justify the problem with the same research questions and method, but with some limitations in terms of the materials and the schedule.

\subsection{Data collection procedure}

In order to collect information, an Individual Background Questionnaire (IBQ) and "Strategy Inventory for Language Learning (SILL)", which was developed by Oxford [11] and adopted to Turkish by Cesur and Fer [2], were used to identify the frequency of use of language strategies of the attendants and to prepare the training program accordingly. As the focus was cognitive strategies, 14 items of this group were chosen as an instrument. It appears that SILL is the 'most often used strategy scale around the world', and the only language learning strategy instrument that has been checked for reliability and validity in multiple ways [12]. After the 20-multiple-choice-question pre-test was applied, a presentation of the strategies was made by the researcher in order to inform the experimental group about learning strategies in general. The cognitive strategies training program was carried out during students' regular Reading \& Writing classes for 11 weeks, 1 or 2 lessons for each, according to the flow of the weekly program with readily-prepared materials for activities. Its purpose is to raise awareness with reading texts and activities. After the post-test, the feedback of the participants about the training of cognitive strategies were also collected and the responses were investigated.

As to the students' some sample answers to SILL, which was applied before the strategy program, it has been found that experimental group does not tend to skim first before reading the whole text. The highest rate to this item was "somewhat true" $(35 \%)$. The item which has the highest rate (39\%) for "always or almost always true" is "I watch English language TV shows spoken in English or go to movies spoken in English", which indicates that students like real life settings. This item has a similar and the highest percentage (44\%) in the control group, as well. In the control group the item that follows this one with the percentage of $28 \%$ is "I look for words in my own language that are similar to new words in English". That is to say, students are prone to learning a word with a Turkish definition instead of an English definition or synonym.

\subsection{Participants}

The research group was composed of 77 students (CEFR B1-B2) attending the preparatory class in Department of Foreign Languages at TOBB Economics and Technology University (TOBB ETU DFL) in Ankara in 2015-2016 Academic Year. There were 41 females and 36 males. When the demographical information in the Individual Background Questionnaire (IBQ) was analyzed, it was found out that most of the students graduated from Anatolian 
High Schools both in the experimental and control groups. All students were between 18-25 ages. Besides, most of the students stated that they have been learning English for 6-10 years (experimental group 66\%, control group 50\%). The subjects were also asked to report on their staying in a foreign country, and they expressed that only 7 (17\%) out of 41 students in the experimental group and $8(22 \%)$ out of 36 students in the control group answered "yes" to this question. Neither the students in the experimental group nor in the control group studied in a preparatory school in a different university before. As a measure to language self-efficacy, the students were asked to rate themselves on a scale as poor, fair and good to indicate how successful they perceived themselves to be in English. Most of them reported that their level is average (fair, experimental group $85 \%$; fair, control group $69 \%)$.

\subsection{Data analysis}

Data elicited from the pre-test and post-test scores were analyzed using SPSS 20. The statistical analysis between the achievement scores of experimental and control groups was carried out through paired t-test technique in order to find out if there is a significant difference. P-value of $<0.05$ was considered statistically significant.

\section{Results and discussion}

Results of the first question: Is there a significant difference between the comparison of pretest and posttest scores of both experimental and control groups?

On the basis of the pre-test and post-test scores of both experimental and control groups, Table 1 presents statistical analysis of paired samples t-test results.

Table 1. Paired sample t-test results of the pretest and posttest scores

\begin{tabular}{|c|c|c|c|c|c|c|c|}
\hline & & $\mathrm{N}$ & Mean & $\begin{array}{l}\text { Std. } \\
\text { Dev. }\end{array}$ & $\mathrm{df}$ & $\mathrm{t}$ & $\mathrm{P}$ \\
\hline \multirow{2}{*}{ 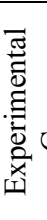 } & $\begin{array}{c}\text { B17 } \\
\text { pretest- } \\
\text { postttest }\end{array}$ & 21 & 2,523 & 2,112 & 20 & 5,475 & 0,000 \\
\hline & $\begin{array}{c}\text { B18 } \\
\text { pretest- } \\
\text { postttest }\end{array}$ & 20 & 1,550 & 1,538 & 19 & 4,507 & 0,000 \\
\hline \multirow{2}{*}{ 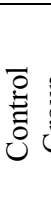 } & $\begin{array}{c}\text { B12 } \\
\text { pretest- } \\
\text { postttest }\end{array}$ & 15 & 1,400 & 1,882 & 14 & 2,881 & 0,012 \\
\hline & $\begin{array}{c}\text { B15 } \\
\text { pretest- } \\
\text { postttest }\end{array}$ & 21 & 1,571 & 4,272 & 20 & 1,685 & 0,107 \\
\hline
\end{tabular}

$\mathrm{p}<.05$

According to the results, the experimental group (B17 and B18) resulted in a significant increase after the training program. On the other hand, $\mathrm{p}$ score for the control group B12 is 0.012 , which means this is a significant increase, too. However, its mean score is 1,400 which means it is still lower than the experimental groups. Also, p score for other control group is 0,107 and there isn't any significant increase. When the means are compared, more specifically, the emerging picture is that there were significant differences between in favor of the students in the experimental group.

Results of the second question: Is there a significant difference between posttest scores of both experimental and control groups? 
As to the second question of the study, paired sample t-test was used to compare the post-test scores of the experimental and control groups.

Table 2. Paired sample t-test results of the posttest scores

\begin{tabular}{|c|c|c|c|c|c|c|}
\hline & $\mathrm{S}$ & $\mathrm{M}$ & $\begin{array}{c}\text { Std. } \\
\text { Dev. }\end{array}$ & $\mathrm{df}$ & $\mathrm{t}$ & $\mathrm{P}$ \\
\hline $\begin{array}{c}\text { Post test } \\
\text { scores of } \\
\text { experimental } \\
\text { and control } \\
\text { group }\end{array}$ & 42 & 2,000 & 3,781 & 20 & 2,424 & 0,025 \\
\hline
\end{tabular}

$\mathrm{p}<.05$

Two experimental and two control groups were analyzed together within themselves. The results indicated that $\mathrm{p}$ score is 0,025 as is seen and according to Cohen's standard, this is a large effect. Apart from this, experimental group's posttest mean score is 16 out of 20 , yet control group's posttest mean score is 14 out of 20 .

Results of the third question: What is the overall opinion of the experimental group about the cognitive strategy training program?

When the students' feedback was evaluated, it was concluded that the training about cognitive strategies had a positive impact on the participants and overall, the students were pleased with the strategy training program. Based on the comments, we can deduce that they mostly benefited from skimming, scanning analyzing expressions. They stated that these strategies were useful not only in developing their reading skill, but also in exams. Actually, taking into account that most reading passages include questions regarding main idea and details, the students who answer these questions make use of skimming and scanning. However, the experimental group's advantage is being aware of the strategy usage and therefore, making out more easily and quickly. Some samples from students' comments are as follows (The statements in the quotation marks are direct translations of the students' comments):

"Thanks to these techniques, my reading scores have increased considerably." (P1)

"Dividing the word into pieces, finding its root and part of speech help me to understand sentences more easily. I learned to guess the meaning of a word without looking up a dictionary." (P2)

"We used to read texts just like reading a book, but when we learned the strategies this term, we made a difference." (P3)

"I can get the meaning more easily now. I wish I could practice more and improve my reading." (P4)

\section{Conclusions and suggestions}

The results of this study reveal that awareness raising activities about cognitive strategies have an impact on TOBB ETU DFL students' development of reading comprehension skills in foreign language teaching. The results regarding the first research question indicate that there is a significant difference in the comparison of the pretest and posttest scores of the group which raised awareness about cognitive strategies in reading skill as opposed to the group which was not exposed to any training. As might be expected, the findings obtained from this study are consistent with the general results of previous language learning strategy studies. A previous research conducted by Çetinkaya [4] presents that repeating strategy is the third out of 20 strategies in terms of frequency of the usage by the 
participants. Apart from that, guessing the meaning, which is similar to analyzing expressions, rank eight in the experiment.

Regarding the second research question, it is seen that there is a large effect on behalf of the experimental group, as well. Based upon these findings we can deduce the strategy training program has affected the students positively. In another research where cognitive strategies were studied, Chun $\mathrm{Ou}$ [3] searched for the effect of summarizing strategy on Taiwanese students who just started learning English. It was concluded that summarizing has an effect on improving reading comprehension. Apart from answering detail questions, it also developed students' getting the main idea and inference skills. Therefore, these findings are in concordance with our claim, too.

Finally, according to the third question of the study, the participants' viewpoints were positive regarding the experiment. Their feedback includes getting more efficiency in the reading process, saving on time and following the text more easily. Taking these points into consideration, it can be concluded that incentive and efficient reading activities, getting some tactics to analyze the texts and enjoying their own learning affected the students' reading comprehension skills constructively.

The most significant suggestion regarding the findings of the study is the need to incorporate the strategies into the curriculum and explicitly teaching students how to make use of the strategies for meeting their individual language needs. In doing so, these results may be used for pedagogical purposes with respect to English language learning in Turkey. As strategy usage affects students' participation, interest and learning processes positively, it could be beneficial to encourage them to use the same strategy in a variety of texts. Alternatively, it is worth mentioning that focusing on other skills (listening, writing etc.) by using the same strategy group could be another study area. I can also be advisable to analyze the students' mistakes in detail and focus on the strategies where most errors are targeted.

\section{References}

1. Alyas, A. Metacognitive Strategies to Foster Learner Autonomy in EFL Reading. (Master's Thesis, Hacettepe University/Institute of Educational Sciences, Ankara)., (2011).

2. Cesur, M. O. \& Fer, S. Dil Öğrenme Stratejileri Envanterinin Geçerlik ve Güvenirlik Çalışması Nedir? Yüzüncü Yıl Üniversitesi, Eğitim Fakültesi Dergisi, IV, II, 49-74., (2007).

3. Chun Ou, F. The Effects of the Summarization Strategy on Reading Comprehension of non-Proficient Taiwanese University EFL Learners. (Phd Thesis, The University of Kansas)., (2006). http://sunzi.lib.hku.hk/ER/detail/hkul/5000363.

4. Çetinkaya, G. Anadilinde ve Yabancı Dilde Okuma Sürecine Yönelik Gözlemler: Okuma-Anlama Stratejileri Üzerine Uygulamalı Bir Çalışma. (Master's Thesis, Ankara University/Institute of Social Sciences)., (2004).

5. Demirel, Ö. Yabancı Dil Öğretimi. Ankara: Pegem Yayıncılık. (2012).

6. Ghasemi, Y. Cognitive and Metacognitive Strategies Employed by Iranian and Turkish EFL Learners. (Phd Thesis, Hacettepe University/Institute of Social Sciences, Ankara)., (2010).

7. Hong-Nam, K. \& Leavell, A. G. Language learning strategy use of ESL students in an intensive English learning context. System 34, 3, 399-415., (2006). https://doi.org/10.1016/j.system.2006.02.002

8. Karapınar, A. The Relationship between Reading Strategies of English Language Teaching Freshman Students and their Achievement. (Master's Thesis, Hacettepe University/Institute of Educational Sciences, Ankara)., (2014). 
9. Mendi, H. B. The Relationship between Reading Strategies, Motivation and Reading Test Performance in Foreign Language Learning. (Master's Thesis, Marmara University/Institute of Educational Sciences, İstanbul)., (2009).

10. O'Malley, J. M. et al. Learning strategy applications with students of English as a second language. TESOL Quarterly 19, 3, 557-584., (1985).

11. Oxford, R. Language Learning Strategies: What Every Teacher Should Know. Boston: Heinle \& Heinle., (1990).

12. Oxford, R., \& Burry-Stock, J. A. Assessing the use of language learning strategies worldwide with the ESL/EFL version of the strategy inventory for language learning (SILL). System 23, 1, 1-23., (1995). https://doi.org/10.1016/0346-251X(94)00047-A

13. Özçaylak, S. The Development of Students' Use of Reading Comprehension Strategies in English Texts. (Master's Thesis, Çă̆ University/Institute of Social Sciences, Mersin)., (2013).

14. Richards, J., \& Platt, H. Longman Dictionary of Applied Linguistics. (2nd ed.). London: Longman Group Ltd., (1992).

15. Rubin, J. Learner Strategies: Theoretical Assumptions, Research History and Typology. Englewoods Cliffs, NJ: Prentice Hall, (Chapter 1)., (1987).

16. Sadık, S. Effects of Strategy Instruction Focus Activities on Students' Reading Strategy Use. (Master's Thesis, Bilkent University/Institute of Social Sciences and Economics, Ankara)., (2005).

17. Tuncel, F. An Integration of Metacognitive Reading Strategies in English Lessons. (Master Thesis, Çă̆ University/Institute of Social Sciences, Mersin)., (2014).

18. Vidal, R. J. Is there a correlation between reported language learning strategy use, actual strategy use and achievement? Linguagem \& Ensino 5, 1, 43-73., (2002).

19. Wilkes, J. C. A Case Study on Primary School Student's Perceptions about their Use of Language Learning and Reading Strategies and Strategy Training. (Master's Thesis, Bilkent University/Institute of Educational Sciences, Ankara)., (2011). 